ISSN: 2162-3104 Print/ ISSN: 2166-3750 Online

Volume 8, Issue 4 (2018), pp. 1926-1940

(C) Journal of International Students

http://jistudents.org/

doi: $10.5281 /$ zenodo. 1482777

\title{
Iranian Student Experience \\ Pursuing Admission to Universities in the United States
}

\author{
Theresa S. Hefner-Babb \\ Lamar University, United States \\ Rezvan Khoshlessan \\ Lamar University, United States
}

\begin{abstract}
This qualitative phenomenological study investigated the challenges faced by Iranian students during the admissions process at a mid-size southern university in the United States. Researchers used a convenience sample from Iranian masters and doctoral degree applicants admitted for the 2015-2016 academic year. Using face-to-face interviews researchers collected responses from seven Iranian students currently in the first year of their graduate programs. The overarching question guiding the study concentrated on the challenges experienced by Iranian students during the university admissions process. Focused questions included a discussion of specific challenges faced by Iranian students. The results from the interviews led the researchers to common themes that resonated across all three focused questions and a student recommendation on ways to streamline the process.
\end{abstract}

Keywords: admissions, challenges, international, Iranian, United States, university

The global setting of higher education is changing and providing more alternatives for students (McLachlan \& Justice, 2009; McKenna, 2015). Between the early years of 2000 and today the number of international students in United States universities and colleges has increased to over one million (Open Doors, 2016). Moreover, the Institute of International Education (2016) reported that 5,764 international students were admitted to U.S. universities through their organization. Andrade (2006) and the Institute of International Education (2015) found a rise in the number of international students in English speaking countries such as, the United States of America, the United Kingdom, Australia, and Canada to name a few. The Institute of International Education (2015) found that among respondents worldwide, the vast majority of prospective students - 74 percent - listed the U.S. as their top choice for college. Human Resources No.110-73 (2007) concluded that the mobility of students around the globe has increased the competition among schools in and out of the U.S. 
This group of students are defined with the temporary term "international student" as they enter their temporary home and the country where they intend to study. Once these students return to their home country upon completion of their studies their visa status and temporary identity will no longer exist (Bista \& Foster, 2016).

Open Doors (2016) reported that 1,043,839 students enrolled in U.S. universities with $60 \%$ of them coming from China, India, Saudi Arabia, and South Korea. China is ranked as the leading place of origin for international students entering the U.S., with $32 \%$ of the total student population; this is followed by India at 16\%, and Saudi Arabia and South Korea with 6\% (Open Doors, 2015). The number of Iranian international students totaled 12.269 in 2015/16 (Open Doors, 2016) and ranked as the 11th most prevalent international student population in the U.S. Prior to the Islamic Revolution in Iran in the 1970s, Ditto (2014) reported that Iran was the number one country of origin for international students entering the United States. Further, 1982/83, several years after the Islamic Revolution, saw the largest group of Iranian international students admitted to U.S. universities and colleges (Ditto, 2014). Ortiz, Chang, and Fang (2015) found that the majority of international students studying in the U.S., U.K., Australia, and Canada came from families of upper-middle-income economies and were financially supported through scholarships and waivers by their home countries.

Springer, Reider, and Morgan (2017) stated that the college admissions process has become a challenge for many students and their families. They added that this challenge and existing competition among students have led many students to apply to a number of colleges instead of one or two, resulting in a decline in admission rates. Stephens (2013) noted that the international and domestic admissions process is quite different. The main focus of colleges should be to ensure the integrity of the admission process and the quality of the students who are accepted. Thus, there is a need to find a way to make the process easier and less stressful for international students.

Human Resources No.110-73 (2007) and Stephen (2013) claimed that international students and scholars are very beneficial for the United States because they support the economy by bringing in money and because their intelligence, creativity, and knowledge lead to greater innovations in the U.S. market. Altbach (1985) added international students will also benefit by studying in America. They will gain skills that help them confront poverty and economic crisis in their own countries. Moreover, Human Resources No.110-73 (2007) noted that when these students achieve critical roles in international organizations in their countries, a familiarity with and respect for American values is created and contributes to global understandings. This globalization and cultural diversity leads to cultural understanding and cooperation among domestic and international students (Tobias, 2015). Therefore, international students contribute to positive relations between U.S. and their home countries (Nikias, 2008). Finally, the acceptance of international students in U. S. universities increases the opportunity for trade and investment abroad for the U.S. government and other countries (H. R. No. 110-73, 2007 \& NAFSA, 2013) that creates a global understanding and work bond which mostly helps to develop positive relations between U.S. and their home countries (Nikias, 2008).

Stephens (2013) concluded that "by improving and regulating the international recruiting and admissions process, expanding enrollment rather than displacing in-state residents, and taking on smaller numbers of international students from a more diverse pool of countries, universities would help to ensure that U.S. higher education remains the envy of the world" (p.59). Therefore, the U.S. government has a responsibility to provide a suitable environment for international students. 


\section{LITERATURE REVIEW}

Human Resources No.110-73 (2007) stated that the United States has always put effort into attracting international students to its colleges and universities. The Institute of International Education (IIE) (2017) announced the results of a new study of admissions officers, which showed that even though the environment for international student's needs improvement, the international students are still interested in attending higher education institutions in the United States. Skinner (2009) asserted that since the late twenty century, the United States has been trying to originate an international education policy to ease visa requirements, ease high-priced tuition costs, and increase scholarships for international students.

Human Resources No.110-73 (2007) noted that many international students dream of being admitted to U.S. universities because of the well-known strengths of the educational system. However, according to Ortiz, Chang, and Fang (2015), and Trines (2017), the number of international students' admission and enrollment has leveled off due to the high cost of obtaining a degree in the United States compared to other countries. The Human Resources reported that the visa policy of the American embassies in other countries was also a barrier for international students willing to enter and study in the United States.

Open Doors (2016) reported a seven percent increase over the prior year in the number of international students who identified as graduate students. The overall number of international undergraduate students reduced from 24\% in Fall 2016 to 22\% in May 2017 (Institute of International Education, 2017). In addition, enrollment patterns varied according to place of origin and academic level. One out of every three international students studied in California, New York, or Texas. Open Doors also identified California as the top host state, New York City as the top host city, and Engineering followed by Business and Management, as the top fields of study in the United States of America. Interestingly, in the 2015-2016 academic year the number of undergraduate international students was higher than that of graduate students $41 \%$ compared to $37 \%$ (Open Doors, 2016).

Fischer (2010) reported that before the Islamic Revolution of Iran in 1979, Iran had the largest number of international students in the U.S., but after the revolution, there was no longer a U.S. Embassy in Iran. A report issued by the Human Resources No.110-73 (2007) noted that after the 1978 overthrow of the Shah in Iran, the number of international students admitted to U.S. colleges and universities decreased, especially among Iranian and those of Middle Eastern descent. This decline in admission reached the highest point after the September 11, 2001 attack on the World Trade Center but stabilized by 2007. The number of Iranian international students reported was 12,269 in the fiscal year 2016-17 (Open Doors, 2016). The Trump administration's decision to bar citizens of several Islamic countries including Iran from entering the U.S. reduced the number of Iranian international students entering U.S. institutions of higher education and increased the admission challenges Iranian international students face (Trines, 2017). Now, about one out of every 85 international students is Iranian.

Political conflicts around the globe resulted in a decline of the students going abroad for college degrees and in the number of international students entering the U.S. (Altbach, 1985 \& Fisher, 2010). The number of international students was higher in 2008 following the global recession of 2007/2008; this recession skewed the numbers, increasing international student enrollment particularly in U.S. universities, but that bump has since been corrected (Choudaha, 2016). Fischer (2017) also indicated uncertainty over the admissions process and noted this 
decision made by the Trump administration to bar travelers and students has reduced the speed of the issuance of students' visas.

Altbach (1985) reported that international students prefer studying in the U.S. for reasons including: scholarships for international students, facilities for advanced research, and opportunities for general international life experience. McKenna (2015) confirmed that most international students pay for their education in the U.S., which is the most expensive in the world, with personal or family funds. About 20 percent receive funding from their respective American institution, while a smaller percentage receives funding from colleges or governments in their home countries. OECD (2017) reported that financial support of universities helps students and reduces the burden of high tuition fees. They added that at least $75 \%$ of students in Australia, England, and the United States benefit from public loans and scholarships.

Human Resources No.110-73 (2007) argued that the cost of higher education abroad was the most significant barrier in rebuilding the number of international students in higher education. Renehan (2015) stated "the most pressing concern in higher education amongst students, prospects, and parents is high tuition" (p. 1). Enrollment of these students in the U.S. is crucial because they are future global leaders. Human Resources No. 110-73 (2007) argued that America's mission in the coming century must be to welcome talented international students and provide opportunities for them to study, teach, and conduct research.

Given the importance of admission and enrollment of international students, Human Resources, No. 110-73 (2007) suggested lowering the cost of higher education for talented international students by offering scholarships, welcoming international students through marketing, removing misperceptions, and improving their language learning abilities. This study aims to examine whether Iranian students confront similar challenges during their admission process in U. S. universities that were reported to confront in other studies. These challenges include: cost barrier, language barrier, visa policy barrier (Altbach, 1985; Ghafarian, 1987; Hart \& Coates, 2010; H.R., No. 110-73, 2007; Skinner, 2009).

Skinner (2009) explained that foreign student advisers must decide that each international student has satisfactory academic preparation to enter school, appropriate Englishlanguage ability, and sufficient funding to cover the total cost of tuition, room, board, fees, books, insurance, and so forth, while studying in the United States. Further, the U.S. consulates abroad determine which students receive visas. If a visa officer determines that a student does not fit the criteria or if the officer determines that the student has intent to immigrate (or has otherwise misinterpreted his or her intent) the visa may be denied.

Ginther and Elder (2014) found language-proficiency test scores for international students had little impact on admissions decisions. They reported this perception existed that English-language proficiency test scores are of questionable value and the problem might be the tests not the students' lack of knowledge. They found that international students reported a lack of familiarity with the different types of language-proficiency tests, including: TOEFL, IELTS, and PTE. Skinner (2009) emphasized that the challenges of international students are: learning the English-language, adapting to differences in education systems, differentiating the philosophy/purpose of education, learning styles, and coping with social, religious, and economic values. International students arrive with their own strategies for coping, studying, and socializing which usually do not fit the existing culture and must be modified.

Ghafarian (1987) found that, once admitted, Iranian students accepted into U.S. colleges, confronted additional problems such as acculturation and mental health issues. Iranian males more easily adapted American values and behaviors than Iranian females, suggesting that this is because "the men have been accustomed to freedom, self-determination, and exposure to the 
western world" (p.569). OECD (2017) stated that one out of every four female international student choose majors such as engineering, manufacturing, and construction. On the other hand, three out of four choose to study in health and welfare fields.

Harvey and Welch (2017) studied a group of international students whose families remained at home. These students lived alone and far from their spouse and children during their years in college. Among these students, the researchers "identified a hidden world of emotional trauma, psychological stress, and negativity, specifically related to relinquishing their role in the family" (p.748).

\section{RESEARCH METHOD}

The purpose of this phenomenological study was to investigate the challenges and supports that exist for Iranian students during their admission process in one mid-sized southern university in the United States. Iranian students who are studying abroad now or have studied abroad in the past claim to have experienced many difficulties throughout their stay into the United States (Hart \& Coates, 2010; Trines, 2017). Results of this study will assist in better understanding the challenges and barriers for future admission of Iranian students coming to study to the U.S. The research questions posed during this inquiry were:

1. What challenges do Iranian students experience through the admission process?

2. What supports are available for Iranian students?

3. What are your recommendations for improving the admission process for other Iranian students?

Marshall and Rossman (2006) stated that strong qualitative research has to have a solid rationale. The proposal of this study strongly convinces the reviewers that the study is important and would benefit international students going through the admission process. Both Iranian students who are studying abroad now or have studied abroad in the past claim to have experienced many difficulties throughout the process of admission and enrollment (Hart \& Coates, 2010; Trines, 2017; Fischer, 2017). Therefore, this study was designed to investigate the admission process of seven Iranian students who were accepted as international students in one mid-size southern university in America.

According to Creswell (2014), qualitative studies must define terms that readers may not know or the specific sense of which in the context of this study may not be clear. This study employed the following definitions:

1. Globalization: the interrelation and connection of nation-states and regions which build up through the international economic, social and cultural intercourse and goes beyond borders (Zheng, 2010).

2. International students: individuals enrolled in higher education institutions who are contemporary student visas (Stevens, Emil \& Yamashita, 2009). , and Shapiro, Farrelly and Tomas (2014) defined an international student as "a student who moves to another country (the host country) for the purpose of pursuing tertiary or higher education e.g., college or university" (p.2).

3. Graduate students: individuals in a graduate school seeking an advanced degree such as a masters or a doctorate degree (Stevens, Emil \& Yamashita, 2009).

The purpose of this phenomenological inquiry was to investigate the challenges and supports that exist for Iranian students in their process of admission in one mid-sized university in southeast Texas. Because the purpose of this study was to investigate and understand the 
challenges, barriers and supports for future admission of Iranian students, a phenomenological approach was chosen (Creswell, 2014). A phenomenological method of qualitative research examines the participants' experience according to their circumstances and conditions. Creswell argued that there is a need for primarily in-depth interviews in the process of collecting information for a phenomenological study. Moreover, in order to describe the meaning of the phenomenon, the participants' experiences are an important in this method.

Themes and concepts become visible in a qualitative study and help the readers understand the participants' experiences better and more deeply (Creswell, 2014). According to Marshall and Rossman (2006), a narrative analysis is an "-interdisciplinary approach with many guises-" (p. 22). In this approach the researcher seeks to describe the meaning of an experience as narratives about their lives.

Denzin and Lincoln (2000) stated that one common form for interviews involves an individual in a "face-to-face verbal interchange but they can also be structured as group interchanges, mailed or self-administered questionnaires, and telephone surveys" (p. 645). They can take place in a structured, a semi-structured, or an unstructured format. In a phenomenological study, it is recommended to use in-depth interviews to collect information (Creswell, 2014; Denzin \& Lincoln, 2000).

\section{Participants}

This study investigated the Iranians' admission process through in-depth interviews. Seven international students were interviewed and asked about their challenges, barriers, supports, and recommendations for improving the admission process for other students. This university is diverse with more than 14,000 students, approximately, more than 600 of whom were international students according to the Texas Higher Education Coordinating Board (THECB, 2015). This study examined the experiences of seven international graduate students during their admission process and first year of college, of whom five were male and two female students. They were studying for their Master's and Doctorate degree and were admitted for the academic year 2015-2016. The participants' connection to the phenomenon maximized understanding of the research problem (Lincoln \& Guba, 1985).

The participants' age ranged from 25-35. One female was studying for a masters' degree in industrial engineering and the other for a masters' degree in chemical engineering. Two of the males were studying for their doctorate degree: one in Industrial Engineering and the other in Civil Engineering. The three others were enrolled in the Master's programs, one is studying Electrical Engineering, the other Mechanical Engineering and the third student interviewed was studying Chemical Engineering. For each participant, the time from deciding to apply for the university in the U.S. to starting class in the U.S. was different. The average time they had been in the U.S. was less than twelve months. The confidentiality of the information in this study was a prior factor and all the participants were protected and their names were not revealed. The use of all the collected data was for scholarly purposes and for helping the institutions recognize and seek resolutions for an easier admission process for Iranian students interested in studying in the U.S.

The in-depth interview is a technique used by qualitative researchers which creates deep meaning in the process of data collection (McMillan \& Schumacher, 2006). The interviews were conducted in the researcher's office at her work place. Researchers used face-to-face interviews to collect data from a sample of seven Iranian students after the approval of human subject research application by the university IRB committee. Interviews were recorded on a digital audio 
recorder, and then transcribed for analysis. To analyze data, the researcher followed recommendations by Creswell (2003), for qualitative research data analysis, which involves arranging and structuring the data, coding the data, and finally representing the data. Creswell (2014) mentioned the importance of the use of a question protocol, "a predesigned form used to record information collected during an observation or interview" (p. 135). He added that the protocol helps the researcher in taking notes and organizing the thoughts.

The following questions were asked from the participants:

1. What challenges do Iranian students experience through the admission process?

2. What supports were available for Iranian students?

3. What are your recommendations for improving the admission process for other Iranian students?

The interviewees were asked to read and sign the consent form. Then the purpose of the research was explained to each participant before the interview questions were discussed. The key emphasis during the collection of the data was to ensure the interviewee's that the researcher carefully related the experiences together in order to make sense and convey the desirable meaning.

In this study, the researcher conducted a semi-structured interview with each participant. Guided questions in the form of a question protocol (Creswell, 2014) were applied which allowed further exploration as the themes emerged. The guiding question and the answers of the interviewees were controlled and read by each participant to ensure the appropriateness and also to ensure the soundness of the report (Moustakas, 1994). The interviews were recorded on a digital audio recorder, and then transcribed for analysis. Notes were also taken by the researcher to further reflect the details of the topics. Through the interview several questions developed and evolved in order to improve the report and perceived the theme in mind.

Data was collected from the in-depth interviews transcripts of the interviews. Since the methodological approach was phenomenological with in-depth interviews, the data analysis employed techniques from both methods. In some instances, there was an overlap in the techniques that were used (Creswell, 2014).

Following Creswell (2014), the researchers organized data into electronic documents based on transcripts. The researcher read the transcripts and made comments and interpretations. Finding patterns, the data were then classified according to themes and meanings. Each participant's experience was written down, analyzed, and compared in order to create better and meaningful themes.

Moustakas (1994) advised that each participant's experiences should be identified and described as significant statements to open-ended questions and then combined into themes. The researcher gave meaning to the gathered information in her findings and presented them as themes so that others would be informed of the participant's experiences and be able to use the results of the findings in a timely way.

Reflectivity is the researcher's personal examination of the research problem which is performed by choosing the specific data and participants and also by interpreting all the needed information and material properly (Lincoln \& Guba, 1985). Furthermore, reflectivity is important for establishing credibility of a qualitative study (McMillan \& Schumacher, 2006). Merriam (2002) introduced "the member check" strategy to gain the trustworthiness of a qualitative research (p. 26). In this strategy the participants comment on the researcher's interpretation in order to ensure the credibility of the study. Therefore, in order to establish trustworthiness in this study, the participants were asked to review the researcher's synthesized interviews for truthfulness (Creswell, 2014; Marshall \& Rossman, 2006). The researcher's interpretation of the 
data was established to be similar to the participants' interpretation, which helps to establish the credibility of the qualitative design. Moreover, Marshall \& Rossman (2006) stated that the study design reveals the intention of the researcher and must ensure that the data and their interpretations will be strong and credible. To ensure credibility, the final task performed in this study was "peer debriefing" where the researchers "discuss their emergent findings with critical friends to ensure that analyses are grounded in the data" (Marshall \& Rossman, 2006, p. 40).

\section{RESULTS}

The purpose of this phenomenological narrative inquiry was to investigate the challenges and supports which exist among Iranian students in their process of admission in a mid-sized university in southeast Texas. This study gave voice to the lived experiences of international students from Iran who are willing to study in the U.S. and are admitted in U.S. colleges and universities. In the process, the study provides insight into the Iranian student experience that can help the U.S. government and university officials to simplify and improve the admission process for these students.

Research Question One explored the challenges Iranian students experience through the admission process. Emergent themes included: visa appointment/issuance problems, obtaining transcripts, money issues/payments for the admission process, and application/acceptance deadlines of universities.

Iranian students research various university programs here in the United States and contact faculty prior to applying. Students reported looking at the professions, articles, and areas of interest of the faculty prior to reaching out to the faculty member. They look for faculty with the same research interests and reach out to them via email to find out if they could work with them as graduate students. Once they receive a response from the faculty member they begin the process of applying for admission to the university. International students prefer not to apply to multiple universities because of the cost related to submitting multiple admission applications. Students also struggled to meet deadlines for graduate school applications in the United States because of problems obtaining documents and paying related fees in U.S. dollars.

Once the students collect all of the necessary documents and successfully apply to a university they wait for their I-20 form which could take up to at least two weeks to arrive. Part of the problem lies in mailing the document since services like UPS, FedEx or DHL are not available from the United States to Iran. Some students who have family in the United States have the document sent to their family in the U.S. and the family member forwards it to Iran. However, that is not always the easiest way for students to obtain their visa since often the immigration document is mailed in a way that requires a signature upon delivery.

When asked about challenges they faced gaining admission to the university all of the students reported problems obtaining visas to travel from Iran to the United States. Iran does not have a U.S. embassy thus the students interviewed reported going to Dubai, Turkey, Romania, Turkmenistan, and Germany to obtain their visa. Once the student receives their I-20 document they need to begin the process of obtaining their visa. The application process requires an appointment and often multiple days to complete so students must incur additional costs related to travel including airfare, lodging and meals.

Students reported varied experiences during the application process and their interviews with the embassy staff. One student mentioned that it is impossible to know what the interviewing officer will ask or what evidence to bring to the appointment despite there being a list of required documents because occasionally additional documents not on the list are requested. Another 
reported that getting a visa necessitated a large amount of research and reading related to the rules and the required forms. This same student indicated that they spent a great deal of time studying the experiences reported by other international students but also including Indian and Chinese students' experiences in their research.

Once their application is complete the students receive one of three color slips: white (accepted), yellow (background check required), pink (denied). Students who receive the yellow slips return to Iran and wait for an email message stating that their visa is ready. Some students experience further delays because of their intended program of study. Chemical Engineering requires that the student obtain documentation from the program stating they will not have access to sensitive information and tools. When students receive notification that their visa is ready they need to turn over their passport to the embassy because the visa is stamped in the passport. Some students reported confusion and concern about receiving single versus multiple entry visas permission which in effect allowed them to enter the United States but they had to stay until their degree was completed and if by any chance left the country, they had to repeat the student visa application process at the U.S. embassies available in other countries.

Every student reported problems obtaining the transcripts necessary to apply to university in the United States. Iran has two types of universities, public and private, and the ease of obtaining degree information varies greatly between them. A student who competes for a place in the public university and is accepted will go to university for free but cannot get a copy of their transcript until they pay the government. A student has two options: to pay the money back (each degree has a different price), or work for the government for a period of time to be determined by their major. Another factor involved which affects male students is military service. Those who are not are exempted have to do a two year military service before their degree is cleared for release. Once the debt is repaid then the student will receive their degree. In addition, a student must indicate their intention to return to Iran after they graduate via a letter of intention to hire or some other documentation to the U.S. embassy. Students who attend private universities pay for their degree as they go through school so they get their transcripts soon after graduation.

The next step for a student is getting their transcripts translated into English and approved by the government which again is time-consuming and also costly. Then they often encounter the need to get them evaluated by a company in the United States. Universities need to know whether the courses in the student's undergraduate and graduate programs are the equivalent to courses offered at U.S. schools. The cost for a transcription to be translated and notarized can be prohibitive for students who need to complete their admission request for multiple applications. To obtain a transcript evaluation the student must send an official transcript to a company who will then submit their findings to the university. Often each school requires a specific transcription service and this can increase the expense related to applying to multiple universities.

Students reported problems paying fees related to university admissions in the United States because of the financial system in Iran. U.S. application websites and forms often required a credit card which is not a form of payment permitted in Iran. Some students opted to work with a company to process all of their admissions paperwork. These companies take care of paying application fees and other international fees but the service is expensive, almost double the cost of the original fees. Other students have a family member or friend who is in the United States pay their fees to avoid problems related to not having a credit card.

Students who apply to the university in the United States are required to take entrance exams like the GRE and the TOEFL. One issue the students face is the need to take the exams and pay for them with a credit card. Again, many students have family members help them with this process. The other challenge students encounter is the challenge of taking the GRE exam 
with a very limited knowledge of English. In most cases the students find that they need to complete language preparation courses before their acceptance to the university.

Students often require letters of recommendation as part of the application process to graduate programs. The delay between asking for a letter and receiving it can extend to two or three months according to one account. Some of the related challenges include the need to ask for the letter in person, since emailing a professor for a recommendation is not an accepted practice, and some professors consider it rude for students to approach them for letters at all.

Research Question Two explored the supports that were available for Iranian students. Emergent themes included: support from their university, that is, the international office, their department, and professors; support from family who were their parents or siblings; and support from their friends.

In the interviews, students mentioned two main offices that provided support for them through the admission process. First, it was their Department/College which frequently considers the student's' needs and accommodates them. Since students had financial problems most departments would either offer full scholarships or waivers for in-state registration. These scholarships helped the students tremendously and reduced their worries of how money could be sent to them from Iran if needed. Second, the international office answered common questions for students during the admission process.

One student reported that his professor's recommendation letter was submitted to the U.S. embassy and the department chairs in U. S. also helped students by sending the documents requested by the embassy officer to the country where they were interviewed. Some majors are very sensitive and embassy officers need to know in detail what the purpose of the student's study is and what the focus of the research. Another student shared that his professor picked him up from the airport because the international office did not provide shuttle service at that time of the night.

Students who had on-campus jobs were also appreciative of the university. They described how having a job helped them pay their expenses and reduced their stress and worries of how money will be sent to them from Iran. A student who had recently gotten engaged requested a raise in his salary and his advisor was able to accommodate him and he immediately accepted. The professor even wrote a recommendation letter for his future wife to submit to the officer at the immigration interview and helped with the process of bringing his wife to the U.S. from Iran.

Students appreciated the support of the international office throughout the admission process. One stated that the welcome from the international office was very warm and the registration process was well-organized and routine. Another student showed appreciation when the international office sent his I-20 to his family in Houston and through them his I-20 was sent to him in Iran. Another stated that one of the staff members in the international office helped her hasten the initial acceptance of the admission process by accepting her recommendation letters from Iranian professors via email. The international office provided immediate service for a student who had recently gotten engaged and issued an I-20 for her to apply for an F2 visa.

Open doors (2016) reported 67\% of the primary source of funding for international students in the U.S. came from a personal or family account. Only $17 \%$ of international students received scholarships or waivers and were help by colleges or university in America. Students who applied for U.S. universities reported that they could have not paid the expenses without the support they had from their parents and siblings. One mentioned that his uncle picked him up from the airport, took him to his house which was about two hours from the student's college, 
and helped him enroll in school. This student stayed at the dorm so he would not commute every day, could make friends and could improve his English.

Another student said that her relatives helped her by opening a bank account, buying essentials for the dorm, and getting a phone contract. They also gave her advice on the enrolment process, so when she came to the university, she did not feel lost. One student had support even prior to arrival. She was advised and helped through the initial admission process in the university and later on when she first arrived in U.S. She also received help with registration and finding off-campus housing.

Some students who had family members or friends flying to Iran in that time period preferred their I-20s to be sent to family and friends they had in U.S. Then these people deliver the I-20 to the student prior to the embassy interview. Otherwise, if they waited for it to be sent via mail they would possibly confront two barriers: one, getting lost on the way to Iran because of it going through a third country or two, reaching the student after several weeks or even months. To reduce the stress of missing the interview or registration deadline, some students chose to have their I-20 delivered from the U.S. by a family member or friend.

A student claimed that she could not have survived in U.S. the first months without the emotional support of her friends. Her friend would call and give advice when needed and help the new student when she confronted issues at school or with other students. Her friend informed the student of cultural differences and how to cope with this new environment. Another declared since she arrived late and missed the student orientation, she was lucky that some Indian students on campus showed her around and helped her explore the campus.

Research Question Three explored the recommendations of the Iranian students for improving the admission process for other students. Emergent themes included: making the admission process easier, providing greater job opportunities, making housing more affordable, and providing better and cheaper health insurance.

A student showed concern about the GRE and TOEFL score deadlines. She recommended that the Admissions Office should not set a submission deadline for the results of the language proficiency tests and accept all documents as results of scores sent to the university through the testing companies. They should give students the option to defer to the following semester if the student does not have the required documents ready in the acceptance period. Lamar Universities has policy that mandates students repay the application fee and go through the admission process from the start each semester which is a barrier and cost-effective.

One student suggested allowing students to send their translated official transcripts as scanned copies via email and then provide the original document in person at registration once the student has arrived in the country, rather than sending it through an evaluation company, which is costly and time-consuming because poor relations between the U.S. and Iranian governments. She requested that letters of recommendation be accepted via email rather than as a mailed letter their professors in their home country was also requested to be sent via email not as an enclosed letter because the postal service causes delays and loss due to poor governmental relationships. Finally, a student requested that embassies as well as universities not be so strict and accept scanned documents.

One major reason that one student chose this university even though it ranked lower than other universities where she was accepted was that the costs were lower. She recommended giving job opportunities to students in the engineering department at the Master's level and not just to Doctoral students. If they could be assigned as Research Assistants there would be an increase in willingness of students to choose universities that rank lower in the Ranking List of Universities in U.S. This additional job opportunity would increase enrollment because 
international students are looking for a university who will hire them and pay for their tuition and provide a research related job in their field of study.

Professors do hire students as teaching assistants for particular courses but this work is unreliable because the course may not be taught in some semesters. This changeability causes stress on behalf of the student who needs financial support. One recommended assigning students as a teaching assistant through the years of study and having them keep the position regardless of the course taught.

There is an option for students to stay in the dorm all through their academic years but it is quite costly for international students especially Iranians whose currency value is lower than many other countries especially the U.S. One international student suggested a price reduction or waiver for students in need, and if that not possible, providing a free temporary room upon arrival so the student has time to find a place he/she can afford to stay.

It is mandatory for all international students and their immediate family living with the student in U.S. to have full health insurance coverage. This is an expense that cannot be waived or paid by the university. This causes issues financially for the majority of international students who have no financial support. One student recommended reducing the price of the insurance, especially for the spouse and children. But unfortunately, it costs twice as much as the student premium.

The International Office provides free shuttle service for new international students upon arrival at the airport but they have to be at the airport at a certain time. One student arrived at 8 $\mathrm{pm}$ and had to wait at the airport till the next morning for shuttle pick up because the taxi was too expensive. So he suggested there not be a time restriction on shuttle service. A student who has been on a flight for more than 20 hours really suffers and gets a bad first impression by having to stay at the airport all night when he has arrived.

A student recommended that the university provide a group or a team to help prospective and interested international students navigate in the admission process. She suggested assigning international students to local or other present international students to get information about the admission process. Another student requested a more detailed welcoming package from the university with all needed information such as life in the U.S. as an international student, cultural differences, a city map with free public transportation service, and how to get involved in student organizations. The International Office, a student suggested, should set up seminars or post detailed information about life in U.S. and introduce difference lifestyles and cultures of students on their website. One student recommended the International Office have knowledge of Iran's admission process and be less strict on deadlines and allow them to send their documents as received not as required and if the student misses the university deadline for documents, the university should extend their application to the following semester rather than making them begin the admission process from scratch.

There was a student who recommended educating other students (international and local) about Iranians and Muslims. She had confronted issues with her roommates and even classmates due to false political and religious reports in the media. She experienced students keeping distance from her because of her country of origin. She suggested putting sanctions on political opinions on campus so no student would be hurt physically or spiritually.

\section{CONCLUSION AND IMPLICATIONS}

The number of international students in the U.S. continues to grow (IIE, 2013). International students create a global understanding and work bond that leads to development of positive 
relations between U.S. and their home countries (Nikias, 2008). Students reported similar challenges and necessary supports in all areas related to pursuing education in the United States. Thus, there is a need for higher education institutions to continue to find ways to make the admission process less stressful for international students.

This phenomenological study investigated the challenges and supports of Iranian students during the admissions process in a mid-size southern Texas university. Researchers concluded that Iranian students aspiring to study in the U.S. experienced a lengthy, and sometimes costly application process. Each student offered a unique account of their experience with no two alikeThe results of this study support (Ditto, 2014) findings. Additionally, it was concluded that a strong support system before and after coming to the United States was important (NAFSA, 2013).

\section{REFERENCES}

Altbach, P. G. (1985). The foreign student dilemma. Retrieved from: http://www.eric.ed.gov/PDFS/ED277284.pdf

Andrade, M.S. (2006). International students in English-speaking universities. Journal of Research in International Education 5 (2), 131-154. doi: 10.1177/1475240906065589

Bista, K., \& Foster, C. (eds.). (2016). Global perspectives and local challenges surrounding international student mobility. Hershey, PA: IGI Global.

Creswell, J. W. (2014). Research design: Qualitative, quantitative, and mixed methods approaches (4th ed). Thousand Oaks, CA: Sage.

Choudaha, R. (2016). Campus readiness for supporting international student success. Journal of International Students 6 (4). I-V.

Choudaha. R, Chang. L (2012). Trends in international student mobility. WES - World Education Service.

Denzin, N. K., \& Lincoln, Y. S. (2000). Handbook of qualitative research (2nd ed.). Thousand Oaks, CA: Sage.

Ditto, S. (2014). Red tape, iron nerve: The Iranian quest for U.S. education. The Washington institute. Improving the quality of U.S. Middle East policy. Policy Focus 133.

Hart, D. J. \& Coates, N. F. (2010). International student complaint behavior: How do East Asian students complain to their university? Journal of Further and Higher Education, 34(3), 303-319.

H.R. No. 110-73, at 28 (2007).

Harvey, T., Robinson, C., \& Welch, A. (2017). The lived experiences of international students whose family remains at home. Journal of International Students, 7(3), 748. doi:10.5281/zenodo.570031

Fischer, K. (2010). China props up foreign students' numbers in U.S. (cover study). Chronicle of Higher Education, 57(13), A1-A25.

Fischer, K. (2017). Even in limbo, the travel ban reverberates. Chronicle of Higher Education. pp. A14A18.

Ghafarian, S. (1987). The acculturation of Iranians in the United States. The Journal of Social Psychology, $127(6), 565-571$.

Ginther, A., \& Elder, C. (2014). A comparative investigation into understandings and uses of the "TOEFL iBT" ${ }^{\circledR}$ Test, the International English Language Testing Service (Academic) Test, and the Pearson Test of English for Graduate Admissions in the United States and Australia: A Case Study of Two University Contexts. "TOEFL iBT"® Research Report. TOEFL iBT-24. ETS Research Report. RR-14-44. ETS Research Report Series.

Institute of International Education (IIE). (2017). Interest among international students holds steady for fall 2017. Retrieved from: https://www.iie.org/en/Why-IIE/Announcements/2017-07-06-IIESurvey-of-College-Admissions-International-Students-Fall-2017 
Institute of International Education (IIE). (2016). Leading places of origin. Retrieved from: https://www.iie.org/Research-and-Insights/Open-Doors/Data/International-Students/LeadingPlaces-of-Origin

Institute of International Education (IIE). (2015). What international students think about U.S. higher education: Attitudes and perceptions of prospective students from around the world. Retrieved from http://www.iie.org/ /media/Files/Corporate/Publications/What-International-StudentsThink-About-US-Higher-Education-2015.ashx

Institute of International Education (IIE). (2014). Open doors 2014: International students in the United States and study abroad. Retrieved from: http://www.iie.org/Who-We-Are/News-andEvents/Press-Center/Press-Releases/2014/2014-11-17-Open-Doors-Data

Institute of International Education (2013). We can do more: Challenges of Iranian students wishing to study in America. Selfscholar: Law, Human Rights, and Education in the Middle East.

Lincoln, Y. S., \& Guba, E. G. (1985). Naturalistic inquiry. Beverly Hills, CA: Sage.

Marshall, C. \& Rossman, G. B. (2006). Designing qualitative research $\left(4^{\text {th }}\right.$ ed.). Thousand Oaks, CA: Sage.

McLachlan, D. A. \& Justice, J. (2009). A grounded theory of international student well-being. The Journal of Theory Construction \& Testing, 13(1), 27-32.

McMillan, J., \& Schumacher, S. (2006). Research in education: Evidence-based inquiry (7th ed.). Boston, MA: Allyn and Bacon.

Merriam, S. B. (2002). Qualitative research in practice: Examples for discussion and analysis. San Francisco: Jossey-Bass.

Moustakas, C. (1994). Phenomenological research methods. Thousand Oaks, CA: Sage.

NAFSA (2013). In America's interest: Welcoming international students. Report of the strategic task force on international student access. NAFSA: Association of International Educators.

Nikias, M. (2008). Attracting foreign students to America offers more advantages. Retrieved from http://www.usc.edu/academe/faculty/private/8009/

Nikias_Attracting_Foreign_Students_to_America_Offers_More_Advantages_2.pdf

OECD (2017). Education at a glance: OECD indicators. OECD Multilingual Summaries. Retrieved from: http://dx.doi.org/10.1787/626b1524-en

Open Doors Report (2015). Open Doors 2015: A quick look at international students in U.S. Retrieved from http://www.iie.org/Research-and-Publications/Open-Doors/Data/InternationalStudents/Infographic

Renehan, Stewart. (2015). Rising tuition in higher education: Should we be concerned? Visions for the Liberal Arts, 1(1), 1-16. Retrieved from: http://scholar.oxy.edu/liberalarts/voll/iss1/3

Skinner, K. (2009). International students: The global commerce of higher education. Retrieved from: http://education.stateuniversity.com/pages/

2129/International-Students.html

Shapiro, S., Farrelly, R., \& Tomas, Z. (2014). Fostering international student success in higher education. Alexandria, VR: TESOL press.

Springer, S. P., Reider, J., \& Morgan, J. V. (2017). Admission matters: What students and parents need to know about getting into college ( $4^{\text {th }}$ Ed.). San Francisco: Jossey-Bass. A John Wiley \& Sons Brand.

Stephens, P. (2013). International students: Separate but profitable. Washington Monthly, 45(9/10), 55-59.

Stevens, D. D., Emil, D, \& Yamashita, M. (2009). Mentoring through reflective journal writing: a qualitative study by a mentor/professor and two international students. Reflective Practice, 11(3), 347-367. DOI: 10.1080/14623943.2010.490069

Texas Higher Education Coordinating Board (2015). Texas higher education data. Retrieved from http:// www.txhigherdata.org

Tobias, S. P. (2015). International students bring many benefits to Kansas colleges, educators say. Wichita Eagle, The (KS). 
Trines, S. (2017). Déjà vu? The rise and fall of Iranian student enrollments in the U.S. WENR-World Education News \& Reviews. Retrieved from https://wenr.wes.org/2017/02/educating-irandemographics-massification-and-missed-opportunities

Ortiz, A., Chang, L. \& Fang, Y. (2015). "International student mobility trends 2015: An economic perspective". World Education Services (WES). Retrieved from: https://wenr.wes.org/2015/02/international-student-mobility-trends-2015-an-economicperspective

Zheng, J. (2010). Neoliberal globalization, higher education policies and international student flows: An exploratory case study of Chinese graduate student flows to Canada. Journal of Alternative Perspective in the Social Sciences, 2(1), 216-244.

THERESA S. HEFNER-BABB, MLIS, MA, EdD, is an Associate Professor in the Library and currently serves as the accreditation liaison at Lamar University, Beaumont, Texas. Her major research interests lie in the area of United States history, student success, and copyright. Email: storey@lamar.edu

REZVAN KHOSHLESSAN, BA, MA, EdD, is coordinator for the Center for Teaching and Learning Enhancement (CTLE) at Lamar University. Her research interests include higher education, international students, active and collaborative techniques, and study anxiety. Email: rkhoshless@lamar.edu

Manuscript submitted: November 18, 2017

Manuscript revised: May 23, 2018

Accepted for publication: June 8, 2018 